\title{
Integration of Communication and Education of Systematic Theology
}

\author{
by W.G.Tillmans
}

We all know "that communication is not just the prerogative of a few specialists, but a basic dimension in any theological consideration related to the proclamation and deepening of faith"1. Our considerations, however, will apply this common rule to the education of systematic theology. The integration of communication and education at a theological faculty (the study of mass-media included) is often obstructed by the sheer amount of information. Consequently the study of communication appears as a break in the syllabus. After years of informative studies, the students are confronted with the theory and praxis of communication, which seems to them merely the application of theological doctrine already acquired. In this juxtaposition the study of communication is seen as a marginal matter instead of an essential element of theological education. By this juxtaposition the practical and pastoral disciplines are obliged to introduce new theological and pastoral attitudes. These attitudes, of course, lack the necessary continuity with the previous studies and, therefore, of ten evoke negative reactions.

It is my conviction, however, that students should acquire the ability of theologising at the faculty itself. At a "workshop" of theology the importance of communication must be clear both in theory and practice. In order to obtain such an integration of communication we have to introduce a way of thinking which is foreign to theological education in its classical approach. In my concern to find a more "natural" context for education in communication, including the theory and practice of mass-media, I will concentrate my reflections on systematic theology (as an example of the more informative disciplines), in order to show that communication is an essential element of education.

\section{Introduction}

Reflecting upon the necessity of an integrated theory and practice of communication in systematic theology, I will abstract some dimensions of theology as an academic discipline.

Theology cannot exist, of course, without technical research in matters of history, exegesis, bibliography, methodology, etc.

A package of technical knowledge has to be transmitted to the students as a necessary aid in their theological profession. This part of theological education is a learning process of trial and error, in which the practice of communication is merely a matter of wise dosage and assistance to the students. In this case the problem of communication has a general character and occurs in every academic discipline. The technical skills of writing and speaking have to be exercised in all disciplines of theological education. In discussing the specific problem of communication in systematic theology, I will presuppose this general ability of academic communication.

Dr. W. G. Tillmans ocd ist Professor an der Katholisch-Theologischen Hochschule Amsterdam (KThHA). 
The public character of the work of a theologian is a bigger problem, because it is connected with the specific task of systematic theology. At times a theologian is asked to join a public discussion or to treat theological issues in the written or audio-visual media. The public communication in the media touches on problems which cannot be discussed in this paper.

The study of participation by the Churches in the public communication of modern Western society has just started. In the field of public communication the role of the theologian is rapidly changing. His role in the process of public opinion and its formation by mass-media becomes more and more important. $\mathrm{He}$ is often asked to give information and commentary that may clarify the impact which various kinds of official and authoritative communication have in society as well as in the Church. Many a theologian is aware of the ethical and moral difficulties of this fact. In this paper, however, I will limit my exposition to interpersonal communication, which is the more common situation for theological education.

I will emphasise the problem of communication for systematic theology in its speculative aspects of analysis and reflection. In addition to the reflective nature of systematic theology, narrative and practical theologies exist, which influence the communicative character of theology in general.

In narrative theology a particular story (in scripture or tradition) is considered an example of divine election, and, therefore, of divine revelation in history. By reading the story and putting its significance into words, the ancient facts can be given the function of a mirror for present experiences; the ancient story evokes a disclosure in our time. Communication in this type of theology approximates the situation and technique of the proclamation of faith in its several aspects. Systematic theology appreciates also the praxis of faith in everyday life and its reflection by practical theology, in search for new or better models for this praxis. The effort of practical theology facilitates dialogue with the daily life of Christian people, which remains necessary for current and significant systematic theology. Both the narrative and practical aspects of theology affect the problem of communication in theology. Frequently their special demands bring life to this problem.

In this paper, however, I will concentrate on the reflective exercise of theology and its specific difficulties of communication. In my opinion, the very essence of the theological profession in the Church and in society depends on the effort of integrating communication and theological education.

Therefore, I start with some remarks about systematic theology in the light of the hermeneutical approach which now seems almost universally accepted ${ }^{2}$. These principles of theological studies will lead us to clear consequences concerning the present problem of communication. This paper will conclude with concrete models as illustrations of educational possibilities.

\section{Some principles}

Theological reflection, like faith in general, is situated in time and space. The object of faith, God in his revelation, is necessarily mediated throughout history. Under the influence of developments in exegesis and philosophy, what we call historical consciousness has arisen in systematic theology. Starting with the fact of incarnation, Christian faith aims at finding God's own mystery in human expressions. These expressions of scripture, tradition and present experiences, locate the event of revelation 
in history. Scripture itself originated in the witnessing and proclamation of faith by the early community, i. e. the answer of faith itself ${ }^{3}$. This answer is considered a constitutive element of revelation. As an exploration of faith, theology only exists therefore in the work of interpretation; it is the reflection, a posteriori, of the living faith and its expression in the past and present.

Theology cannot exist outside the environment of the living community of faith. The emphasis on the community of believers as a starting-point for theological reflection is a hermeneutic attitude which presupposes first of all that human existence realises itself in a way different from the mere being of matter, namely by a continuing confrontation with the world in which it lives; and furthermore that God's presence realises itself as revelation by means of human history. Our faith in revelation as an outline for life is based upon the concrete experience of Israel and of the apostles and evangelists, who bear testimony of Jesus and are thus the beginning of ecclesiastical tradition". The insight, that both the "natural" and the "supernatural" have to be discovered in human existence brought about a general process of penetrating theology with hermeneutics. The result is that from now on theological research takes place in two clearly differentiated phases: research into the origins of the proclamation of faith in scripture, tradition and present time, and - based upon this further reflection which may lead to faith's actual significance. In addition the hermeneutical approach to the mysteries of faith brought about a revaluation of the rhetorical, doxological and symbolic speech of the Church in scripture and tradition. These consist of "first-order" proclamations, symbolical models, which always precede and determine the "second-order" proclamations, the theoretical models". Within this general hermeneutical framework the problem of communication has to be examined because the problem is connected with the primordial importance of language for human and Christian existence.

Until recently our theological tradition, originating culturally from medieval scholasticism, described faith as a process of finding truth. The presupposition was the clear distinction between subject and object. Truth as an adaequatio rei et intellectus could be seen as an objective absolutum clearly distinguished from human knowledge and experience which were considered as possible (subjective) areas of error. Theology has now made an epistemological break with the past. The old metaphysical theology has come to a dead end as far as both objectivity and subjectivity are concerned ${ }^{\text {s}}$.

The apparent relationship between the human being as subject and the world as object cannot be maintained any longer as a realistic one. The object as such does not occur in nature; it is the result of human activity and vision, because the subject always interferes with the object. In fact a new insight arises in the relationship between human being and environment. Things have meaning to people because they come to them in a language which at the same time tells something about people themselves. Nothing is plain with the human being, because nothing is directly present in him or her; language places everything at a distance. In reading the bible, in understanding tradition, and in dialogue with the modern world, theological reflections are always embedded in pre-existing language.

Contemporary attention to the essential dimension of language constituting human existence makes the problem of communication a particularly serious one. In communication between people, between people and God, language (both verbal and corporeal) cannot be understood as an instrument to be used or not. The believer does not have at his or her disposal an external instrument called language, but human exist- 
ence itself is expressed and supported by language. The life of the human being cannot be thought of without language and corporeality.

This presence of language in human existence signifies also the end of an old contention of subjectivity. Formerly, philosophy started with the epistemological presupposition that man can have his experiences at his immediate disposal and that language, in all kinds of corporeal expression, is only the external "translation" of the given content of subjective existence. Human beings, however, are not subjects opposed to objects, but are always (as in language) connected with the object and by means of language become subjects.

Theological reflections, therefore, are situated in and stimulated by the context of language. Reflection itself enters into a hermeneutical circle of faith which is mediated in the language of the community. From this fact we can draw important consequences for the integration of communication in theological reflection.

\section{Some consequences}

\section{Dialogue}

The first consequence of our considerations on faith and language is the need for dialogue. Dialogue is an art that is required for theology and for an exchange with other disciplines. The art of dialogue lies in the ability to be objective; moreover, it lies in the inner freedom that makes commitment to hermeneutical theology possible. It also lies in the ability to understand and respond with an open mind, anticipating further developments of thought. Finally, dialogue presupposes the ability and the skill to use all the technical knowledge of tradition and its interpretation.

The art of dialogue, however, is far more difficult when the theologian has to speak with people who are not trained in theology. First the theologian has to find a common world of language and of mutual understanding ${ }^{7}$; to achieve this he must be conscious of the common humanity of all people and then he must take a personal stand.

In interdisciplinary dialogue, the theologian has to see and hear with his or her own eyes and ears, using specific skills of observation and analysis. Someone who can only "talk theology" will never truly become a theologian. Theological expression meets here the same limits and is governed by the same laws as the proclamation of faith in catechesis and worship.

\section{Community}

The primordial importance of the community of faith is a second consequence of our reflections. The theologian must be rooted in a community which represents a tradition in which he or she can experience faith ${ }^{8}$. There is a big difference in communication in the context of the universal church and in the local church. The theologian has to be aware of the tension between universal and local contextual theology, and therefore must express and clarify this tension to the local church. It becomes more and more necessary for the theological profession to be embedded in a local community of faith and to speak in the specific context of a community. Theology must understand the comprehensive contexts of the experience of faith and reflect these in an active and imaginative language inside and outside worship situations. True theological discernment is only possible in involvement with a local church, when the 
theologian can function as doctor ecclesiae, as a true intermediary between the local and universal churches.

The work of the theologian in a local church has to be more than rational, based on personal commitment. This is the only way in which typical human and Christian concerns in local situations can be developed. In understanding tradition and present condition, hermeneutical theology will explicitly consider its own point of view, its own form of prejudice and Vorgriff. Consequently the theologian has to draw on his own experience and imagination (i. e. an encounter with reality far deeper and wider than its rational explanation) which is rooted in the community of the local church.

\section{Experience}

The emphasis on experience of faith in the specific experience of human reality is the third consequence of hermeneutical theology $y^{\theta}$.

The theory of the priority of doxological and symbolic language in the communication of faith gives a special importance to human experience ${ }^{10}$. In the communication of faith in general, but also in the specific work of clarification and reflection, this experience forms an indispensable link. Human experience depends on a particular situation, a particulary history and the anticipation of the future. Theology is always a secondary activity reflecting on experiences and placing them in the context of the history of salvation. This means that experience is directly connected with reflection. Reflection is meaning, clarification, justification and systematisation of experience.

Theological reflection, of course, only operates at a distance from experiences and their direct expression. Theological reflection uses technical language instead of the preceding symbolic and natural language. The use of technical terms serves the academic concern for demonstration and verification. In this technical translation of the Christian faith, however, two points should remind the theologian of the limitations of such language ${ }^{11}$.

First of all, the language which theology uses is always conditioned by cultural concerns which are inherent in the choice of terminology. These concerns account for the significance of the terms and their effective power of enlightenment. The enlightenment which a culture has experienced through its use of these terms, constitutes and structures people's cognitive capacity. The dependence, therefore, on cultural commitments, which may disappear or recede when cultures change, cannot be totally overcome by abstract means. Technical language should never create the illusion that it is outside a shared frame of reference or without loci communes.

Secondly, the disclosure-evoking and self-invoking elements, so prominent in natural language, can never be completely excluded, no matter how over-riding the concern for rationality. The pretention of technical terminology as completely rational, allows the non-conceptual elements to reassert themselves in uncontrolled ways which make them hard to identify and to accept. The theologian must always guard against attributing a "crypto-religious" status to his second-order reflections. This is also the reason why the so-called "kerygmatic" theology has never been accepted. It would merely be a translation-theology based on the illusion that theology itself is possible in isolation from present culture and language ${ }^{12}$. Within the reductio ad mysterium of reflective theology the reductio ad kerygmam has to be present as the actual connection with the living experience of faith in the church.

Therefore, we may conclude that the theologian has to be concerned for the commitment of his speech to the lived experience of faith in the past and the present. 
To avoid too much repetition I will indicate briefly the last consequence which is language and its many forms in human communication. Theology is evidently rooted in a language which determinates the expression of faith. In addition the theologian must be aware of the manifold forms of language as a rhetorical form of communication, combining denotation and connotation, informative and performative elements, models of picture and disclosure. In reality, theology depends on key concepts and models which may be different in the various communities of Christians. All theological ways of speaking thus have a limited power to enlighten; they must always be tested by their ability to disclose the mystery. It is not just the concept which does justice to reality, but also the dynamic process of disclosure in the service of which the concept is used. Hence, the adequacy of the concept must be determined, not only by testing its internal reference, $i$. e. in the systematic coherence of reflection, but also by testing its ability to help its user to relate to reality.

All expression of faith, even all experience of faith, is directed and orientated by use of language. In theological education this fact demands sensitivity to language and to the context of its use: to speak theologically you have to speak well.

\section{Models for integration of communication in theological education}

In this survey of illustrative models I will confine myself to models that have been developed explicitly for education in systematic theology. I will not refer, therefore, to the wealth of models used in practical theology.

\section{The seminar}

The seminar is the starting point for a theological education that is integrated with communication. In seminars, as contrasted with lectures, students are involved in the theme by their own contributions and by dialogue among the participants. The seminar is the place to teach the students to distinguish (while reading) between objective reproduction and (subjective) criticism. It is also the place to teach them to write well and to show them (by trial and error) the possibilities of bibliography and documentation. But its main purpose is to introduce the students to the art of theological dialogue. Interpersonal interaction is the model corresponding to this intention, in which theme, group and individual influence each other continuously (in both positive and negative ways) ${ }^{13}$. The so-called "project-study" is the most advanced form of this type of education. During the project a group of students determines the theme, sets up the bibliographical research, evolves the plan of study in continuous dialogue, develops the issue and sets down the results of their inquiry in a final paper.

This type of theological education is based on the conviction, that modern education has to be liberating, i. e. helping the students to become (as soon as possible) autonomous and self-reliant subjects who are responsible for their thinking and speaking in the church and in society.

The method of education consists of an encounter with the students in which the self-reliance is anticipated and supported. It meets the demands that students should acquire the ability of theologising at the faculty itself, and that they should not just acquire knowledge of doctrine for application in practical situations. This method 
also intends to teach students to deal with the distance between objectivation and personal life - a dangerous tension which must be endured and ultimately integrated.

The most difficult task in this form of education is teaching students to express their individual experiences in the group, i. e. to objectivate their experiences to fellow-students and give up a possessive attitude; when they succeed, the objectivated experiences are at disposal of the group for further dialogue.

\section{The reflective seminar}

This type of seminar intends to deepen the interrelation between practical experiences and theological training. The seminar takes place after a semester of pastoral activity by the students; therefore the practical experiences can be submitted to resumed theological reflections. In particular the seminar intends to detect prejudices that influence the students when they perceive their own practical experiences and the questions people ask. In this seminar students learn to distinguish their theological insights from these questions. People often raise problems that students cannot answer from their theological knowledge. In such situations students are tempted to give an answer that is not asked for.

This seminar intends to prevent students from relying on theological jargon, and to teach them to accept the experience that other people (or they themselves) gain, because an open mind is necessary in their future pastoral and theological work.

\section{The discussion seminar}

In this seminar a theologian and a psychologist work together; the students participate in a discussion group in a parish. They take turns in acting as leader of the discussion, reporter, or theological advisor. Each discussion in the parish is followed by a seminar in which the parishioners do not participate.

This seminar intends to teach the students to express their knowledge in a natural language able to relate experiences, to understand questions and meanings outside their own situations of life, and to lead a discussion ad bonum commune. In this way students learn to communicate their knowledge at the right moment and in the right place, and to be aware of the influence that communication exerts on the process of knowing.

In this situation the personal integration of head (rational) and heart (emotional), of knowledge and experience, turns out to be the biggest problem for the students. Some students discuss easily and naturally, but forget all of their theological education and awareness; other students use nothing but theological terms nobody understands, and do not really encounter people and start a dialogue.

Such a seminar may be deepened by a special integration-training by a theologian and a psychologist. During one or two weeks of intense group-process (not unlike a sensitivity-training), the students are instructed how to learn by their experiences in interaction with other people, and to combine this learning with their theological images and insights. 


\section{The mass-media seminar}

In this case I mention only one possibility. In the study of the audiovisual media methods of training have been developed in which it is possible to teach students to analyse their attitudes towards several kinds of programmes, to analyse the programmes and to develop a theological evaluation of the programme in the service of pastoral care and theological reflection ${ }^{14}$. Because of the lack of feedback the mass-media are a form of non-communication at the same time; the world of the mass-media, therefore, cannot be understood purely as a continuation of interpersonal communication. In this context, however, I will stress one point that seems important to me. Mass-media exert a considerable influence on the public image of the Church and its theology. It is impossible to speak about the mass-media as mere instruments that are neither good nor bad. The official documents of the Church about the use of massmedia are not sufficiently aware of the fact that the Church, as a public entity, is already situated by this communication before using it. "The "use and effect" approach to the public media seems to be characterized by a naivete which completely bypasses the analysis of the concrete social reality in which public communication takes place. It overlooks the political and economic mechanisms which determine the structure and function of the public media, irrespective of which 'use and effect' one might dream up for them ${ }^{\text {"15. }}$.

\section{Conclusion}

Systematic theology can only exist as "communication without domination" ${ }^{\text {16 }}$. It is the reflective mirror of communication of faith, of the Church as Sacrament (i. e. the effective symbol of salvation for the world in Jesus Christ). The theologian has to speak a language which is rooted in this world, a common language and not a jargon, a language able to speak from the simultaneity of this world and another world. Theology, as reflection as well as proclamation of faith, depends for its relevance on such a living language. Integration of communication, therefore, must be a continuing concern in the education of systematic theology.

In consequence of our reflections and their conclusions a few suggestions can be made for practical application in theological education.

1. Major disciplines should point out the communicative dimension within the education itself of these disciplines.

2. In pointing out this dimension the specific language and use of the mass-media can be included.

3. On the basis of this primary education further development of the communicative capacities can be entrusted to practical theology. In this case the aspect of communication, both theoretical and practical, can be taught in connection with the totality of theological education and not merely as an instrument of application.

4. In continuity with the integration of education and communication the specific introduction to the world of mass-media may happen in a "natural" way as an aspect of the theological and pastoral formation of the students. 
- The substance of this article is identical with a paper given at the International Seminar on "Integration of Communication and Theological Education" at the Villa Cavalletti, Frascati, Italy, October 13-20, 1981. The seminar was organised by the Centre for the Study of Communication and Culture (London) and the Pontificia Universita Gregoriana (Rome).

1 F.-J. Eilers: Communications as a regular Feature of Theology Training. In: "DIWA Studies in Philosophy and Theology" 5 (1980) 1,45.

2 Cf. the elaboration of this approach and its history by N. Schreurs: De cirkelgang van theologie en geloven. In: „Bijdragen" 42 (1981) 174-202.

8 For this thesis, cf. E. Schillebeedkx: De toegang tot Jezus van Nazareth. In: „Tijdschrift voor Theologie" 12 (1972) 1, 28-61.

4 Cf. H. M. Kuitert: Wat heet geloven? Structuur en herkomst van de christleijke geloofsuitspraken. Baarn 1977.

B Cf. E. Schillebeeckx: Tussentijds verhaal over twee Jezusboeken. Bloemendaal 1978, $18-27$.

- For parallel observations in e.g. sacramental theology, cf. A. Gerken: Theologie der Eucharistie. Munich 1973, 97-156; L.-M. Chauvet: Du symbolique au symbole. Essay sur le sacrements. Paris 1979, 187-208.

7 True dialogue needs a "communion mythique“, cf. R. Pannikar: Témoignage et dialogue. In: E. Castelli (ed): Le Témoignage. Paris 1972, 367-388.

8 This situation is much alike the context of pastoral care; cf. F. Haarsma: Fundamentele communicatieproblemen in de relatie pastor-pastorant. In: G. A. C. Hubers ea.: Fundamentele communicatieproblemen. Bussum 1972, 63-76.

9 About the complexity of using the term experience as a moment in the reflection of faith, cf. E. Schillebeeckx: Gerechtigheid en liefde, genade en bevrijding. Bloemendaal 1977, 25-69; W. Logister: Contrast en harmonie in de christelijke ervaring. In: H. H. Berger (ed): Ervaring van God. Baarn 1979, 48-62.

${ }^{10}$ Cf. H.-J. Schulz: Okumenische Glaubenseinheit aus eucharistischer Oberlieferung. Paderborn 1979.

11 Cf. F.-J. van Beeck: Christ Proclaimed. Christology as Rhetoric. New York 1979, 64 bis 104.

12 Cf. K. Rahner: Kerygmatische Theologie, In: L. Th. K. VI, 126.

${ }^{13}$ R. C. Cohn: Zur Grundlage des themenzentrierten interaktionellen Systems. In: Gruppendynamik 1974, 150-159.

14 Cf. H. Hoekstra \& K. Zöchbauer: Trainingsboek massa-media. Informatie, amusement, reklame. Bloemendaal 1981. For the theological aspects, cf. W. G. Tillmans: Massamedia en symboolanalyse. De theoretische achtergrond van een theologisch onderzoek. In: "Bijdragen" 41 (1980) 88-119.

15 C. Hamelink: Perspectives for Public Communication. A study of the Churches' Participation in Public Communication. Baarn 1975, 27.

10 For the background of this expression, cf. W. Bartholomäus: Communicatie als thema van de theologie. In: „Concilium“ 14 (1978) 1, 108-123.

\section{ZUSAMMENFASSUNG}

Die Integration von Kommunikation und Kommunikationserziehung, einschließlich der Massenmedien, wird innerhalb einer theologischen Fakultät oft allein schon durch den reinen Umfang der Information behindert. Folglich erscheint ein Kommunikationsstudium als eine Unterbrechung innerhalb des Lehrplans. Nach Jahren formalen 
Studiums werden die Studenten mit Theorie und Praxis der Kommunikation konfrontiert, die ihnen als eine reine Anwendung bereits erworbener theologischer Lehren vorkommt. So erscheint das Studium der Kommunikation mehr als eine Randerscheinung denn als wesentliches Element theologischer Bildung. Hier müssen praktische Theologie und Pastoral neue theologische und pastorale Wege zeigen.

In der Reflexion über die Notwendigkeit einer integrierten Theorie und Praxis der Kommunikation innerhalb systematischer Theologie muß man verschiedene Dimensionen der Theologie bedenken. Die Übermittlung technischer Kenntnisse und Forschungsinstrumente der Geschichte, der Exegese, Bibliographie, Methodologie usw. müssen den Studenten als notwendige Hilfe mitgegeben werden. Diese Vermittlung ist ein Lernprozeß, in dem die Praxis der Kommunikation eine Frage der Dosierung und Hilfe für den Studenten ist. Das Problem der Kommunikation hat hier mehr generellen Charakter und gehört in dieser Form zu jeder akademischen Disziplin. Fähigkeiten des schriftlichen und mündlichen Ausdrucks sind in allen theologischen Disziplinen notwendig.

Der öffentliche Charakter eines theologischen Werkes ist ein größeres Problem für die systematische Theologie. Manchmal wird ein Theologe zu einer öffentlichen Diskussion gebeten oder zu einer audiovisuellen Darstellung. Diese öffentliche Diskussion in den Medien kann hier allerdings nicht ausführlicher behandelt werden. Das Studium der Teilnahme der Kirchen an öffentlicher Kommunikation in der westlichen Gesellschaft hat erst gerade begonnen. Dabei ändert sich die Rolle des Theologen im Prozeß der öffentlichen Meinung und der Beeinflussung der Massenmedien sehr schnell.

Hier geht es aber vor allem um die interpersonale Kommunikation, die für die theologische Bildung noch wichtiger ist.

Zugleich mit der reflektiven Natur systematischer Theologie gibt es narrative und praktische Theologie, die den kommunikativen Charakter dieser Disziplinen generell beeinflussen. In der narrativen Theologie wird ein bestimmtes Geschehnis als Beispiel göttlicher Erwählung und deswegen göttlicher Offenbarung in der Geschichte gesehen, die so ein Spiegel für die Gegenwart wird. Hier ergeben sich die verschiedenen Stufen der Kommunikation in der Glaubensverkündigung. In der systematischen Theologie wird die Praxis des Glaubens im täglichen Leben anerkannt, und so erleichtern die Bemühungen der praktischen Theologie den für die systematische Theologie notwendigen Dialog zwischen den Christen.

Das eigentlich Wesentliche des theologischen Berufes in Kirche und Gesellschaft aber wird bestimmt von dem Maße der Integration von Kommunikation und theologischer Bildung.

\section{Einige Grundsätze:}

Theologisches Denken ist eingebunden in Raum und Zeit. Sein Objekt ist Gottes Offenbarung im menschlichen Dasein. Die Schrift beginnt als Zeugnis und Bekenntnis des Glaubens einer frühen Gemeinde, d. h. als Antwort des Glaubens selbst, die ein konstitutives Element der Offenbarung ist. Theologie beschäftigt sich deswegen mit dem lebendigen Glauben der Vergangenheit und Gegenwart. Sie kann nicht außerhalb einer lebenden Gemeinschaft existieren. Dies bedeutet andererseits aber auch die Uberzeugung, daß Gottes Gegenwart sich im menschlichen Dasein und menschlicher Geschichte offenbart. Daraus ergeben sich zwei Phasen: die Erforschung der Ursprünge der Glaubensverkündigung in Schrift, Tradition und Gegenwart, dann aber auch die hermeneutische Dimension der Verkündigungswege der Kirche. In diesem hermeneu- 
tischen Rahmen muß die Frage der Kommunikation beachtet werden, weil er grundsätzlich verbunden ist mit der Bedeutung der Sprache für die menschliche und christliche Existenz.

Nach neueren Überlegungen kann die Beziehung zwischen dem menschlichen Wesen als Subjekt und der Welt als Objekt nicht länger aufrechterhalten werden. Die Dinge haben nur Bedeutung für den Menschen, weil sie in einer Sprache kommen, die zur gleichen Zeit etwas über die Menschen selbst sagen; im menschlichen Wesen aber ist nichts unmittelbar gegenwärtig, sondern die Sprache schafft immer entsprechende Abstände ... Die wesentliche Bedeutung der Sprache in der menschlichen Existenz unterstreicht besonders das Problem der Kommunikation. Für die Kommunikation mit anderen und mit Gott hat der Mensch die Sprache nicht wie ein Instrument, sondern die menschliche Existenz selbst drückt sich aus und wird möglich gemacht durch Sprache ... Theologische Ubberlegungen werden deswegen bestimmt und angeregt durch den Kontext der Sprache.

\section{Einige Folgerungen:}

Die erste Folgerung aus solchen grundsätzlichen Überlegungen ist die Notwendigkeit des Dialogs. Dieser Dialog ist eine notwendige Kunst für die Theologie und den interdisziplinären Austausch. Sie besteht darin, sachlich zu sein und die innere Freiheit zur Verantwortung hermeneutischer Theologie möglich zu machen. Schwierig wird dieser Dialog, wenn er mit Nichttheologen geführt werden soll. Hier muß man erst die gemeinsame Welt der Sprache und des gegenseitigen Verstehens finden ...

Die besondere Bedeutung der Gemeinschaft des Glaubens ist eine weitere Folgerung dieser Uberlegungen. Der Theologe muß in einer Gemeinschaft wurzeln, in der er seinen Glauben erfährt. Es gibt einen großen Unterschied zwischen der Kommunikation im Kontext der universalen und der lokalen Kirche. Der Theologe muß sich der Spannung zwischen universaler und lokaler kontextueller Theologie bewußt sein. Wahre theologische Einsicht ist nur möglich im Leben mit der lokalen Kirche, wenn der Theologe als Vermittler $z$ wischen lokaler und universaler Kirche wirken kann ...

Die Betonung der Glaubenserfabrung in dem speziellen Erlebnis menschlicher Realität ist die dritte Konsequenz hermeneutischer Theologie. Die Theorie von der Priorität der doxologischen und symbolischen Sprache in der Kommunikation des Glaubens schreibt der menschlichen Erfahrung eine besondere Bedeutung zu.

Menschliche Erfahrung aber hängt von der besonderen Lage, der besonderen Geschichte und Zukunftssicht ab ... In der technischen Ubersetzung des christlichen Glaubens aber sollten zwei Dinge den Theologen an die Begrenzung solcher Sprache erinnern, die Bedingung kultureller Bedingtheit und die offenbarenden und selbsterklärenden Elemente der naturalen Sprache. Inmitten der „reductio ad mysterium “ der reflektiven Theologie muß die "reductio ad kerygma" als aktuelle Verbindung mit der lebendigen Erfahrung des Glaubens in der Kirche lebendig sein.

Die letzte Folgerung ist die Sprache. Theologie ist klar begründet in einer Sprache, die den Ausdruck des Glaubens bestimmt ... In der theologischen Bildung fordert diese Tatsache Sensibilität für die Sprache und die Umwelt ihres Gebrauchs: um theologisch $\mathrm{zu}$ sprechen, muß man gut sprechen.

Modelle der Integration van Kommunikation in theologischer Bildung: Hier geht es jetzt um Modelle für die Bildung in systematischer und praktischer Theologie.

Das Seminar ist der Anfang einer theologischen Ausbildung, die integriert ist in Kommunikation. In Seminarien, im Gegensatz zu Vorlesungen, sind die Studenten mit 
eigenen Beiträgen und Dialog am Thema beteiligt. Da ist der Platz, den Studenten beizubringen, wie sie unterscheiden müssen zwischen objektiver Wiedergabe und (subjektiver) Kritik. Hier lernen sie zu schreiben, sie erfahren die Möglichkeit einer Bibliographie und Dokumentation. Interpersonaler Austausch ist das Modell, das dieser Intention entspricht ...

Das reflektierende Seminar versucht die Beziehung zwischen praktischer Erfahrung und theologischer Ausbildung zu vermitteln. Dieses Seminar findet nach einem Semester pastoraler Arbeit statt. Es soll helfen, bestimmte Vorurteile des Studenten aus seiner praktischen Erfahrung mit den Fragen der Leute zu entdecken. Oft fragen Leute Dinge, die diese Studenten aus ihrem theologischen Wissen allein nicht beantworten können. Sie sollen davor bewahrt werden, in theologischen Jargon zu verfallen.

Beim Diskussionsseminar arbeiten Theologe und Psychologe zusammen. Die Studenten nehmen an Diskussionsgruppen in den Pfarreien teil. Sie wechseln sich ab als Diskussionsleiter, Berichterstatter oder theologische Berater. Jede dieser Diskussionen wird mit einem Seminar ergänzt, an dem die Pfarrangehörigen nicht teilnehmen. Dieses Seminar soll den Studenten helfen, ihr Wissen in natürlicher Sprache auszudrücken:

Beim Massenmedienseminar geht es vor allem um eine Möglichkeit: man hat audiovisuelle Lehrmethoden entwickelt, die es den Studenten ermöglichen, ihr Verhalten gegenüber verschiedenen Programmen zu analysieren, Programme zu untersuchen und die theologische Evaluation pastoraler Programme und theologischen Denkens zu ermöglichen. Die Massenmedien sind ohne Feedback gleichzeitig eine Form der NichtKommunikation. Deswegen können sie nicht als eine Weiterführung interpersonaler Kommunikation verstanden werden. Andererseits haben sie einen beachtlichen Einfluß auf das öffentliche Ansehen der Kirche und ihre Theologie. Die Massenmedien sind weder gut noch böse. Die kirchlichen Dokumente über den Gebrauch der Massenmedien sind sich nicht genügend der Tatsache bewußt, daß die Kirche als öffentliche Einrichtung bereits eine publizistische Erscheinung ist. Das reine Gebrauchs- und Wirkungsmodell der öffentlichen Medien scheint bestimmt zu sein von einer Naivität, die eine Analyse der konkreten sozialen Wirklichkeit völlig übergeht. Sie übersieht jene politischen und ökonomischen Mechanismen, die Struktur und Funktion der öffentlichen Medien bestimmen, unabhängig davon, welchen Gebrauch oder welche Wirkungen man von ihnen erträumt.

Systematische Theologie kann nur bestehen als „Kommunikation ohne Vorherrschaft". Sie ist der reflektierende Spiegel der Kommunikation des Glaubens der Kirche als Sakrament. Der Theologe muß eine Sprache sprechen, die in dieser Welt begründet ist ...

\section{Als Folgerungen ergeben sich:}

1. Die größeren theologischen Disziplinen sollten die kommunikative Dimension innerhalb ihrer Ausbildung darstellen.

2. Bei der Darstellung dieser Dimension kann man die Massenmedien mit einschließen.

3. Auf der Basis dieser Grundausbildung kann man die weitere Entwicklung kommunikativer Fähigkeiten der praktischen Theologie überlassen.

4. In Kontinuität mit der Integration von Erziehung und Kommunikation kann die Einführung in die Welt der Massenmedien auf „natürliche“ Weise als Teil der theologischen und pastoralen Ausbildung der Studenten erfolgen. 


\section{RESUME}

En théologie, l'étude de la communication apparait encore plus comme un phénomène en marge qu'un élément naturel. Ici, la théologie pratique et la pastorale doivent montrer de nouveaux chemins. Car la nature de la profession théologique est définie par la mesure de l'intégration de la communication interpersonnelle et de la formation théologique. Les reflexions théologiques sont définies et stimulées par le contexte du langage. Ainsi, suit en premier lieu la nécessité du dialogue que s'avère difficile avec les non-théologiens. Ici on doit d'abord trouver le monde commun du langage et de la compréhension mutuelle. Important est ainsi pour le théologien la communauté de foi où il fait fonction d'intermédiaire entre l'Eglise locale et l'Eglise universelle. L'expérience de foi joue un rôle particulier jusque dans l'usage du langage. Le théologien doit parler une langue qui est fondée dans ce monde. C'est pourquoi la dimension communicative, y compris les mass media, doit être accentuée dans la formation théologique sur cette base, les capacités communicatives doivent continuer de se développer dans la théologie pratique.

\section{RESUMEN}

El estudio de la comunicación social sigue siendo en la teología un fenómeno marginal, más que un elemento esencial. Aquí, la teología práctica y la pastoral deben abrir nuevos caminos, pues la esencia de la profesión teológica viene determinada por el grado de integración entre comunicación interpersonal y formación teológica. La especulación teológica está condicionada por el contexto idiomático. Surge en primer lugar la necesidad del diálogo, especialmente difícil cuando es diálogo con no-teólogos. Debe, pues, encontrarse primero la plataforma común del lenguaje y de la comprensión mutua. Para el teólogo es importante la fé común, en la que puede desempenarse como intermediario entre la Iglesia clerical y la universal. La experiencia de la fe juega un papel importante incluso en la utilización de idioma. El teólogo debe usar un lenguaje enraizado en el mundo. Por ello hay que subrayar en la formación teológica la dimensión comunicativa, incluída la de los medios de comunicación social, pues sobre esta base habrá que desarrollar la capacidad comunicadora de la teología práctica. 